\title{
A Case Study in Statutory Interpretation: Western Union Co. vs. Lenroot
}

\section{Max Radin*}

STATUtory interpretation or "construction" suggests two things to lawyers. One is a certain type of legal language which contains such words as expressio unius, noscitur a sociis, ejusdem generis, in pari materia and other phrases denominated "rules". They are not really "rules" in the sense that they require us to reach one result rather than another in the application of a statute to an action at law, but they do constitute a vocabulary and a method of presentation when for reasons entirely apart from these "rules" and their "exceptions", a result of some kind is reached in the effort to know whether any act is prohibited, commanded or permitted under a statute. This is, of course, what we really mean when we speak of "interpreting" or "construing" a statute.

Now, in a recent important case decided by the Supreme Court of the United States, the case of Western Union Co. v. Lenroot, ${ }^{1}$ the question arose whether the Western Union Telegraph Coinpany might einploy minors under the age of 16 and 18 to drive motor-cars while delivering messages, without violating the Fair Labor Standards Act of 1938. ${ }^{2}$ Five members of the Court (Chief Justice Stone, Justices Jackson, Frankfurter, Roberts and Reed), speaking through Justice Jackson, thought the Company might do so. The minority (Justices Murphy, Black, Douglas, Rutledge), speaking through Justice Murphy, thought they might not.

There was no question that the Western Union Telegraph Co. had employed such minors. Some twelve percent of their messengers were within the described groups. ${ }^{3}$ And there is no question that the employment of these groups comes within the notion of "oppressive child labor" which the Statute means in some way to prevent." The only question was whether or not the Telegraph Compauy was relieved from any liability under the Act by Section 215(a)(1) which

*John H. Boalt Professor of Law, University of California.

1 (Jan. 8, 1945) ........ U.S. ......, 65 Sup. Ct. 335.

252 STAт. (1938) 1060; 29 U.S.C.A. (1942) \$\$201-219.

3 Western Union Co. v. Lenroot, suppra note 1, 65 Sup. Ct. at 336.

429 U.S.C.A. $\$ 203,1$. 
exempts a common carrier transporting in the regular course of its business goods it did not produce.

There could be no doubt, and none is offered, that the Act meant in general to eliminate, or at least greatly to reduce, oppressive child labor. It says so in so many words. Nor can there be any doubt that the purpose of eliminating the detrimental conditions listed in Section 202 runs through the whole act. But another purpose is clearly asserted in Section 215 (a) of the Act, and that purpose is not to interfere by means of this particular Act with the regular course of business of common carriers. Since there are two purposes, there is the possibility, which indeed is presented by this case, that they may come into conflict. It is hard not to assume that of these two, the former purpose is far the more important, and if that is the case, an application of the statute, which permits complete effectuation of the more important purpose and only slightly interferes with the minor one, seems to commend itself.

The majority of the court is doubtless as much opposed to oppressive child labor as the minority. And if the statute had, on the assumption that Congress had the power to do so, unequivocally forbidden such labor anywhere and everywhere, without excepting common carriers, I think all the justices of the Court would have thoroughly approved. But Congress did not do that, perhaps because it doubted its constitutional power to go so far. ${ }^{5}$ And Congress did unquestionably express a purpose in regard to common carriers as well as in regard to child labor.

In the opmion of the majority, if Western Union is permitted to employ as messengers the children under sixteen which it now employs, or even if it employed only such children as messengers, this would leave uneliminated only a small amount of oppressive child labor. Whereas, if the statute is applied to the Western Union, no messages could be sent over the wires of that company until it had ceased the practice, nor for thirty days thereafter. For more than a month, accordingly, telegraph service in the United States for most purposes would cease. This would be, in the majority's opinion, a

5 Justice Jackson at 65 Sup. Ct. 338, 340, discusses the possible doubt as to the constitutionality in the minds of Congress and comes to the conclusion tbat Congress entertamed no doubt. He admits that Hammer v. Dagenbart (1917) 247 U.S. 251 had not yet been overruled, but he declares that the overruling was imminent, and in U.S. v. Darby (1941) 312 U.S. 100 it was overruled. I venture to doubt the absence of Congressional doubt on the matter. It is a parlous thing to be certain that a case will be overruled. 
horrifyingly substantial interference with the business of a coininon carrier and would be a far greater mischief to the public than the admittedly undesirable fact that some thousands of children under sixteen continue to be employed as messengers, within the limits in which state laws permit such einployment, very narrow limits in inany of the states.

On the other hand, the minority is of the opinion that the balance of danger is in the other side. If twelve percent of the Western Union messengers may be children under sixteen, one hundred percent may be, and while state laws will restrict this to a considerable extent, it is precisely in those states in which state laws do not do so, that children most need this protection. This, therefore, is a serious impairment of the large and beneficent purpose of the statute. Against this the suspension of telegraphic service for a month must be balanced. No one can doubt that such a suspension would be an enormous hardship for the entire public. But the minority points out that a stay of the inandate or the injunction for the thirty day period could easily eliminate this particular hardship.

I think it can be said that the minority has the better of the argument so far as the purposes of the statute are concerned. The inain and affirmative purpose would be fully carried out if their opimion had prevailed and the secondary negative purpose need not in practice have been interfered with at all. The majority, on the other hand, admittedly leave a large section of the affirmative purpose unachieved in order to prevent any interference whatever with the other, and clearly minor, purpose.

The objection on this point voiced by Justice Jackson is not convincing. "Nor will we believe," he says, "without more express terms than we find here that Congress intended the courts to issue an injunction which as a practical matter they would have to let become a dead letter, or enforce at such cost to the public, if a defendant proved stubborn or recalcitrant." The injunction beyond the thirty day period would in no sense be a dead letter and this part would of course be far the inost important aspect of it. So far as the suspension of the mandate for thirty days is concerned, surely it is no new or unheard of thing in penal procedure to give a certain elasticity to punishment, if the main purposes of the punishment are otherwise carried out. And equally surely, Justice Jackson does not think that there is no method by which the country could avoid being threatened

${ }^{6}$ Western Union Co. v. Lenroot, supra note 1, 65 Sup. Ct. at 344. 
with cessation of telegraphic service for the time beyond the thirty day period, by a "stubborn or recalcitrant" telegraph company. After all, common carriers are controlled in some fashion by government agencies and it would be obviously intolerable if any person or corporation could say with impunity, "We shall break the law and you dare not punish us because you need us for sending messages." We have, to be sure, legalized monopoly of this busmess by permitting the merger of the two great telegraph companies but we have not quite sunk to the impotence of being helpless against open blackmail. ${ }^{\text {? }}$

But it is worth while analyzing the decision further on the basis of the standard "theories" or "rules" or "principles" of interpretation. We have first the now orthodox procedure of examining the legislative history. Justice Jackson, in the paragraph quoted, says that he did not believe that Congress "intended" a certain result, which must mean there and in other parts of the opinion as in so many other similar assertions in countless opinions, that he believes that Congress did not intend that result. But he also tells us in the first sentence of the last paragraph of his opinion, "Ascertainment of the intention of Congress in this situation is impossible."

If by this statement Justice Jackson is thinking of "intention" in accordance with the meaning usually given it, as an idea or a group of ideas in the mind or minds of determinate human beings, I fully and enthusiastically agree with him. The use of the term, however, generally implies that bloodless and sineviless fiction of interpreters, the imaginary "legislator," le législateur, der Gesetzgeber, the homo legiferens, own cousin to the "economic man". What this spectre thought or did not think, intended or did not intend, imagined or did not imagine, is utterly irrelevant, since he is created for the purpose of having a particular intention of the interpreter imputed to him. ${ }^{9}$ But if we have in mind not this figment, but the actual human beings, several hundred of them, who voted in favor of the Fair

TThe use of the word "blackmail" has no reference whatever to the Western Union Company, but to some irresponsible successor to that Company who might in the face of a peremptory statute expressly mentioning telegraph companies remain "stubborn and recalcitrant." The mischief contemplated by Justice Jackson would be just as great as long as the monopoly lasts.

8 Western Union Co. v. Lenroot, supra note 1, 65 Sup. Ct. at 344.

9I have attempted to analyze the fiction in Statutory Interpretation, (1930) 43 Harv. L. REv. 869-871. 
Labor Standards Act in the House of Representatives and the Senate, Justice Jackson is overwhelmingly right in saying that we cannot possibly determine what their intentions were, beyond the actual words they used in the statute.

We do, of course, know what was the intention of President Roosevelt, who urged this legislation and signed the bill. We have his words quoted both by the majority ${ }^{10}$ and the ninority, ${ }^{11}$ and in our system the President is a substantial part of our legislative machinery. His vote, we may say, is equivalent to the vote of one-sixth of the membership of Congress. But that is far from telling us what was in the minds of the majority, whose approval made the statute. That is to say, we cannot in any way determine what pictures they had in their nind of the activities they were regulating, what their impulses and motives were when they set down or had set down the words of the statute, or acquiesced in them at the time the vote was taken. If the word "intention" meant merely what they proposed to accomplish, it would be equivalent to "purpose" and we might use the terms interchangeably. But it usually suggests the whole complex of mental content, and as such is clearly inaccessible to us.

Indeed, it is quite proper to say that this mental content is not merely maccessible, but irrelevant. We could reach this result logically by approved "rules of interpretation." If the legislators had something in mind which they did not say, their failure to say it is proof that they did not wish it to be the law! But a much better reason is that the constitutional power granted to Congress to legislate is granted only if it is exercised in the form of voting on specific statutes. If all the legislators in the halls of Congress or outside, in exactly similar words orally uttered what was in their minds, that would not be a statute and therefore no law. They are empowered to make law only in one fashion and that is by voting on proposed statutes.

As a matter of fact, nowhere has the futility of attempting to determine what was in the minds of legislators by means of the "legislative history" been so incisively and effectively-I should like to say, so wittily-shown as in Justice Jackson's own opinion when he

10 Western Union Co. v. Lenroot, suspra note 1, 65 Sup. Ct. at 337.

11 Ibid. at 345. Message of the President to Congress, May 24, 1937; H. R. Doc. No. 255 (75th Cong. 1st Sess.). 2. The quotation is fuller in the minority opinion (65 Sup. Ct. at 345 ) than in that of the majority: "A self-supporting and self-respecting democracy can plead no justification for the existence of child labor. ... All but the hopelessly reactionary will agree that to conserve our primary sources of man-power, Government must have some control over . . . the evil of child labor." 
examined the legislative history of the statute. ${ }^{12}$ The successive stages of the bill, the deletions here, the striking out there, the failure to strike out somewhere else, prove precisely that the bill had several stages, that some things were stricken out and other things were not. So far as legislation is a human activity, they are instructive data for social psychology, but they tell us nothing about what we are to do in order to carry out purposes of the statute. We can make no sense of all these things, unless we treat the final result, the statute, as a sort of accord and satisfaction, an Aquilian stipulation, summing up and superseding a vast deal of negotiating hither and yon, and rendering it not only superfluous but improper to go back of it.

That we have taken "legislative history" to our bosom as a method of interpretation is an instance of following after strange gods when we had a better one at home. The common law had developed the rule that the debates in Parliament were not merely inconclusive about the "intention" of a statute, but were incompetent. ${ }^{13}$ Doubtless this goes too far, but it had enormous advantages over the cult of "materials," i.e., debates, drafts, reports, etc., which was the characteristic of the Continental approach to the understanding of statutes. This was found to be a great burden by progressive jurists and it is unfortunate that we chose just this excrescence in the systems of Continental law for invitation, when we were so notably and unreasonably supercilious about other elements in these foreign systems. The phrase, la loi parle par elle-même, ${ }^{14}$ ought to be received back into its former scat of honor.

As I have said, the English rule that makes the legislative history, including the arguments of the proponents-so often mentioned by Justice Jackson-not inerely inconclusive but incompetent seems somewhat excessive. If we are looking, as it seems to me we should look, exclusively at the purpose or purposes which the statute seeks to achieve by means of methods which the statute indicates either as permissible or as exclusive, ${ }^{15}$ we may well examine the legislative

12 Ibid. at 337-340.

13 Maxweli, Interpretation of Statutes (8th ed. by Sir. G. Jackson, 1937) 25, and cases collected in Note t. Cf. also Millar v. Taylor (1769) 4 Burr. 2303, 2332; Rex v. Board of Ed. (1909) 2 K.B. 1045, 1057, 1072. Against this, the older vague reference to the fesors del act is hardly a qualification. Cf. Early Statutory Interpretation in England, (1943) 38 Irx. L. Rev. 16, 36-37, and ibid. at 37, n. 94.

14 The phrase is that of Professor Levy-Ullman justifying the English practice against that of the Continent (1919) 48 BULL. MENS. DE LA SOC. DE LEG. CoMap. 64.

${ }^{15}$ I have set these ideas forth more fully in A Short Way With Statutes, (1942) 56 HARv. L. REv. 388-424. 
history as a guide. No statute can possibly be so explicit and plain that all aspects of its purpose will become at once apparent from reading it. Expressions - even highly rhetorical expressions-uttered on the floor of Congress or in its committees in which purposes of a statute are suggested, are at least evidence that such a purpose cannot be excluded, among the many within the range of the statute's application. But the value of that evidence will, as in the case of other testimony, depend a good deal upon the character of the witness and the forn of the testimony.

So far as legislative history is concerned, Justice Jackson examines it in detail for the majority and finds that it adds up to zero. Justice Murplyy scarcely mentions it. I think we may properly say that Justice Jackson's brilliant presentation amply justifies the deliberate neglect by Justice Murphy.

But "rules of interpretation" are most luxuriantly in operation when we come to defining terms. A statute uses words and words can be defined. Indeed, most statutes begin with a section or sections of definitions. Consequently when we have before us the question of whether Western Union may without violating the child labor provision of the Fair Labor Standards Act enploy children under sixteen as messengers, we can under the rules of interpretation be referred to determining the meaning of the words "goods," "ship" and "produce" within the general prohibition of Section 215(a)(1) and the exception.

Are "messages" goods? Justice Jackson examines the words, finds that by the statute "goods" are equivalent to "articles or subjects of commerce of any character" and finds that under a number of decisions, "ideas, wishes, orders and intelligence" transmitted in the form of telegraphic messages are "subjects of commerce" and are therefore "goods." This is the pure gold of Euclid, the very first of the koinai ennoiai, which we call "axioms," and for purposes of Euclidean geonetry is uninipeachable.

But does Western Union "produce" telegrams and does it "ship" them? Since "produce" is defined in Section 203(j) of the act as "handles" among other things, and since the Company undoubtedly does something about the messages it transmits wlichl looks something like "liandling," we are almost ready to find that it does in fact "produce" the messages because it does "handle" them. But Justice

${ }^{16}$ Western Union Co. v. Lenroot, supra note 1, 65 Sup. Ct. at 341. 
Jackson distinguishes here. He quotes the excepting clause about common carriers and comes to the conclusion that the Company cannot be said to "produce" its telegrams even though in a sense it "handles" them, because whatever "handling" it does, is part of the process of "transporting" a word also used in the excepting clause. Otherwise the statute would read, "The Act shall impose no liability on a common carrier for carrying goods it does not carry", which is patently absurd.

As for the word "ship," the District Court" and the Circuit Court ${ }^{18}$ were at odds about whether the Telegraph Co. "shipped" anything. Justice Jackson remarks:

"We do not think it is necessary for us to resolve the interesting but baffing inquiry as to precisely what, if anything, moves across state lines in the telegraphic process. In its practical aspects, which concern the public, transmission of messages is too well known to require analysis; and in its scientific aspects, which interest the physicist, it is too little known to permit of it." ${ }^{18}$

Papinian would have called the statement "elegant" in form, and in substance it is beyond cavil. And Justice Jackson, finding no definition of "ship" in the statute, goes to common speech and asks whether either scientist or layman would ever speak of "shipping" electrical impulses. He therefore cannot believe that Congress could have "intended" 20 to include a telegraph company among those who must not einploy children under sixteen, although on the previous page, as several times before, he came to the conclusion that "no legislative intent is manifest as to the facts of this case."

Then there is the argument ex silentio. Congress could not have had such a special kind of employer as Western Union in mind. If it had, it would have mentioned telegraph companies or messengers. Justice Jackson admits, to be sure, that Congress has the "right to be indirect where it could be direct," but thinks that here it would have been direct, if it had wished to include telegraph companies.

Perhaps so. Justice Jackson is our best authority in this very opinion for saying that we cannot possibly know. And Justice Murphy ${ }^{21}$ calls attention to the fact that in Section 214 the statute makes

17 Lenroot v. Western Union Co. (1943) 52 Fed. Supp. 142, 149.

18 Ibid. (1944) $141 \mathrm{~F}$. (2d) 400, 402.

19 Western Union Co. v. Lenroot, supra note 1, 65 Sup. Ct. at 343.

201 bid. at 342.

21 Ibid. at 346. 
a special reference to "messengers," and therefore we cannot say that it completely failed to envisage this type of employment.

As for "handling," is it so certain that the only "handling" done by the Company is part of the "transportation" and is therefore excepted? Justice Murphy thinks not. ${ }^{22}$ A great deal of handling goes by the Company in respect of the messages before they are actually converted into that inysterious process that goes on unintelligibly in the wires. Justice Murphy names them: "Before the inessages actually move in commerce, Western Union employees aid in the composition of the messages, write them on blanks, mark the written messages, transform them into electrical impulses and perform numerous other incidental tasks." 23 Why is this different from the "handling" admitted to be the "handling" which is "production" by Justice Jackson? His words are:

"One who packages a product, or bottles a liquid, or labels, or performs any number of tasks incidental to preparing for shipment might otherwise escape the Act, for in a sense he neither manufactures, produces, or mines the goods. We are clear that 'handled' or 'worked on' ucludes every kind of incidental operation preparatory to putting goods into the stream of commerce."24

As far as the word "ship" is concerned, Justice Murphy concedes that linguistically "ship" is not used by people in ordinary speech about sending telegrams. But using approved methods, Justice Murphy points out that in Webster's New International Dictionary, "ship" is made equivalent to "transporting" and unless the Western Union Co. is engaged in "transportation" it is not within the exception at all. ${ }^{25}$

It seems to me quite clear that applying the eminently scholastic methods of definition and distinction, and the processes so eminently successful in mathematics, we could get one result as easily as another. Telegraphic messages could be declared to be "goods," or not to be "goods," sending a message could be "shipping" it, or not, filling out blanks and writing and preparing messages for transmission could be "handling" and therefore "producing," or not, with

22 Ibid. at 345 .

23 Ibid.

24 Ibid. at 342.

25 Ibid. at 346. 
exactly equal logical validity. And just as the inferences made by the government and the Company from the legislative history cancelled each other out because one result could be reached as readily as another, so the conclusions reached by determining what "shipping" means, and "producing" means, cancel each other out, because one good conclusion renders the Company liable and an equally good conclusion relieves it. It certainly seems that if the "integrity of the interpretative process" ${ }^{26}$ really involves the application of this type of logomachy, the outcome of the struggle can scarcely help being in most cases a drawn battle.

Justice Jackson suggests that if the inclusion of Western Union in the penalties of the Act did not entail the enormously serious result of a cessation of telegrams, he might be less inclined to exclude the Company. And the result is, as he says, a consequence of the monopoly the Company has. If there had been competitors, it might make a difference.

"If such a producer using child labor is refused facilities to transport his goods, competitors usually come in, needs are still supplied, and only the offender suffers." 27

The offender in this case, it would seem, has us on the hip..$^{25}$ I venture to believe that if the majority could have been persuaded, as the minority were, that this consequence need not follow at all, sending messages might have seemed "shipping" and preparing and writing and typing them at either end might have seemed "handling" or "producing," to the entire Court.

It is qnite true that the consideration of the consequences of a decision has at all times been a controlling factor in the judicial process. Those courts who declare vigorously that they are completely indifferent to the consequences of what they decide, and would decide as they do though the heavens fell, merely mean that they do not really believe that the consequences will be seriously harmful. If they meant what they said, and acted on it, they would be taking a long step toward the destruction of our judicial system.

26 Ibid. at 344.

27 Ibid.

28 We cannot have things both ways. If we desire the advantages of private monopoly-and it has advantages - we must face the fact that there are also serious disadvantages. 
The majority were therefore fully justified in balancing the result of their decision against the result of deciding the other way. If I prefer the opinion of the minority it is chiefly because I am inclined, with the minority, to doubt the harmful consequences that would have flown from compelling the Western Union to discharge twelve percent of its messengers. In either case I am confirmed in nyy conviction that the ordinary "interpretative process" is rather a technical language to set forth a conclusion than an organon for reaching one. 